Terbit online pada laman web jurnal : http://e-journal.sastra-unes.com/index.php/JIPS

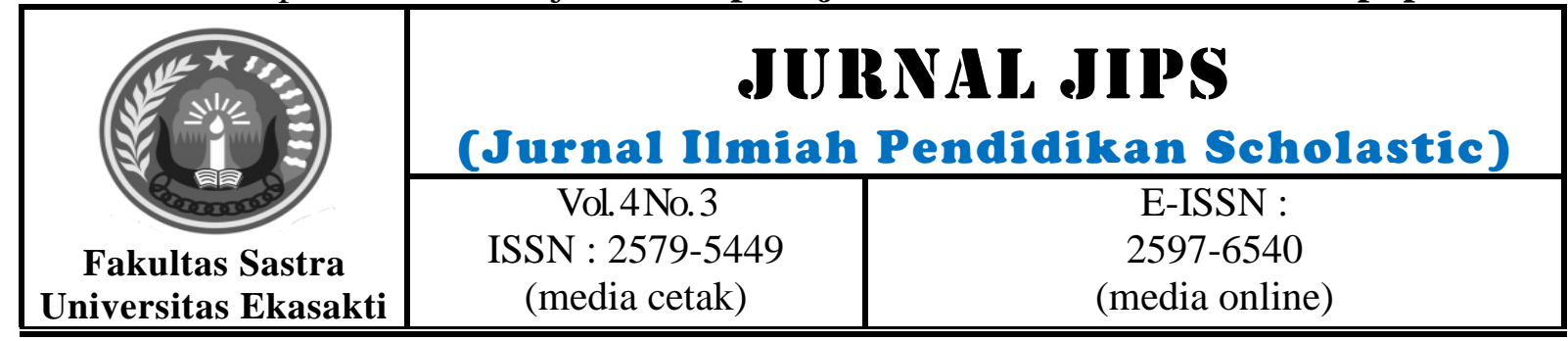

\title{
THE EFFECT OF CREATIVITY ON ENTREPRENEURIAL MOTIVATION
}

\author{
Reni Respita \\ Departement Economic Education, Teacher and Training Education Faculty, Ekasakti University of Padang \\ renirespita35@gmail.com
}

\begin{abstract}
Abstrak
The purpose of this study was to determine the effect of creativity on entrepreneurial motivation in students of the Faculty of Economics, State University of Padang. The population in this study were 1,209 students. The sampling technique used was proportional random sampling in order to obtain a sample of 300 students. The research instrument used was a questionnaire. Data analysis in this study using simple regression analysis. The results of this study indicate that creativity has a significant and positive effect on student entrepreneurial motivation.
\end{abstract}

Keywords: Entrepreneurial Motivation, Creativity

(C) 2020Jurnal JIPS

\section{INTRODUCTION}

Kreativitas merupakan salah satu karakteristik yang harus dimiliki oleh seorang wirausaha. Greene (2008:12) "Successful entrepreneurs are creative. They think of new ways to market their businesses and always look for new solutions to problems". Kreativitas diartikan oleh Suryana dan Bayu (2013:210) sebagai sekumpulan ide baik berupa pengetahuan maupun pengalaman yang berada dalam pikiran manusia yang kemudian digabungkan menjadi sesuatu hal yang sifatnya kreatif. Kreativitas mahasiswa di Fakultas Ekonomi UNP dikategorikan masih cukup/sedang. Artinya, masih sedikit mahasiswa yang mampu memunculkan ide-ide atau gagasan baru yang merupakan salah satu karakterisik yang harus dimiliki oleh seorang wirausaha. Adanya kreativitas juga mempengaruhi motivasi seseorang untuk berwirausaha. Hasil penelitian yang dilakukan oleh Fatmawati (2014) menunjukkan bahwa kreativitas berwirausaha berpengaruh terhadap motivasi berwirausaha mahasiswa. Menurut Sardiman (2012:75), motivasi dapat dikatakan sebagai serangkaian usaha untuk menyediakan kondisi-kondisi tertentu, sehingga seseorang mau dan ingin melakukan sesuatu, dan bila ia tidak suka, maka akan berusaha untuk meniadakan atau mengelakkan perasaan tidak suka, itu. Berdasarkan hasil observasi awal yang dilakukan, motivasi mahasiswa FE UNP untuk berwirausaha masih tergolong rendah. Rendahnya motivasi berwirausaha mahasiswa tersebut ditandai dengan sedikitnya mahasiswa FE UNP yang berpartisipasi dalam mengusulkan proposal PKM, khususnya PKM Kewirausahaan. Tinggi rendahnya motivasi peserta terhadap suatu kegiatan akan menentukan tingkat peran sertanya terhadap kegiatan tersebut, dengan demikian apabila seseorang memiliki motivasi yang kuat atau tertinggi terhadap suatu kegiatan maka akan tampak peran sertanya dalam kegiatan tersebut dan sebaliknya, Hasiah dalam Andriani (2013:167). Berdasarkan fenomena yang diuraikan pada latar belakang masalah dan urgensi penelitian yang telah dipaparkan di atas, 
maka penelitian ini difokuskan untuk mengetahui pengaruh Kreativitas terhadap Motivasi
Berwirausaha mahasiswa di Fakultas Ekonomi UNP.

\section{RESEARCH METHODS}

Jenis dari penelitian ini adalah penelitian survei. Karlinger dalam Riduwan (2010:49) mengatakan bahwa "penelitian survei adalah penelitian yang dilakukan pada populasi besar maupun kecil, tetapi data yang dipelajari adalah data dari sampel yang diambil dari populasi tersebut, sehingga ditemukan kejadian-kejadian relatif, distribusi, dan hubungan antar variabel sosiologis maupun psikologis". Penelitian dilakukan di Fakultas Ekonomi Universitas Negeri Padang pada bulan Desember 2015-Maret 2016. Dalam penelitian ini populasi penelitian adalah seluruh mahasiswa Fakultas Ekonomi
UNP jenjang S1 dan D3 tahun masuk 2013-2014 sebanyak 1.029 orang. Jadi jumlah atau ukuran sampel adalah sebanyak 300 orang dengan presisi sebesar 5\%. Sampel ditarik secara proporsional radndom sampling. Data dianalisis menggunakan analisis regresi sederhana dimana sebelum dilakukan pengumpulan data instrumen telah diuji validitas dan reliabilitasnya. Selanjutnya dilakukan pengujian inferensial dan Uji t untuk menguji pengaruh variabel kreativitas terhadap motivasi berwirausaha.

\section{RESULTS AND DISCUSSION}

Berdasarkan pengolahan data maka diperoleh hasil sebaagai berikut:

Tabel 1.

Analisis Regresi Sederhana Coefficients

\begin{tabular}{|c|c|c|c|c|c|}
\hline \multirow[b]{2}{*}{ Model } & \multicolumn{2}{|c|}{$\begin{array}{c}\text { Unstandardized } \\
\text { Coefficients }\end{array}$} & \multirow{2}{*}{\begin{tabular}{|c|}
$\begin{array}{c}\text { Standardized } \\
\text { Coefficients }\end{array}$ \\
Beta \\
\end{tabular}} & \multirow[b]{2}{*}{$t$} & \multirow[b]{2}{*}{ Sig. } \\
\hline & B & $\begin{array}{l}\text { Std. } \\
\text { Error }\end{array}$ & & & \\
\hline $\mid$ (Constant) & $32.569 \mid$ & 3.137 & & 10.382 & .000 \\
\hline $\mathrm{X}$ & 619 & .064 & .491 & 9.725 & .000 \\
\hline
\end{tabular}

a. Dependent Variabbel: Y

Persamaan Regresi: $\mathrm{Y}=\mathrm{a}+\mathrm{bX}$

Dari persamaan tersebut dapat disimpulkan bahwa terdapat hubungan yang positif antara kreativitas terhadap minat berwirausaha. Jika kreativitas adalah 0 maka motivasi berwirausaha mahasiswa adalah 32.569. Jika kreativitas mengalami kenaikan sebesar 1 maka motivasi berwirausaha akan mengalami kenaikan sebesar 0.619. Semakin tinggi kreativitas maka akan semakin tinggi motivasi berwirausaha mahasiswa di Fakultas Ekonomi UNP.

Berdasarkan tabel 1 menunjukkan bahwa $\mathrm{H} 0$ ditolak (sig $0.00<0.05$ ) sehingga dapat disimpulkan bahwa kreativitas berpengaruh signifikan dan positif motivasi berwirausaha mahasiswa di Fakultas Ekonomi UNP. Uji hipotesis menunjukkan bahwa kreativitas berpengaruh signifikan dan positif terhadap motivasi berwirausaha mahasiswa FE UNP. Dapat diartikan bahwa tinggi rendahnya kreativitas mahasiswa akan menentukan tinggi rendahnya motivasi berwirausaha mahasiswa. Semakin tinggi kreativitas mahasiswa maka akan semakin mempengaruhi motivasinya untuk berwirausaha dan sebaliknya. Penelitian ini membuktikan bahwa kreativitas merupakan salah satu faktor yang menentukan motivasi berwirausaha mahasiswa. Semakin tinggi kemampuan mahasiswa menghasilkan gagasangagasan baru maka akan semakin tinggi pula dorongan dari dalam dirinya untuk berwirausaha.

Dorongan dalam diri mahasiswa untuk berwirausaha baik itu atas dorongan kebutuhan fisik, kebutuhan rasa aman, kebutuhan sosial, kebutuhan pengakuan, maupun kebutuhan aktualisasi diri akan akan timbul karena adanya kreativitas. Mahasiswa tidak akan termotivasi tanpa adanya kreativitas. Kreativitas meliputi kelancaran (fluency) yaitu kemampuan atau kesigapan dalam menghasilkan banyak gagasan. Adanya kemampuan dan kesigapan mahasiswa dalam menghasilkan gagasan atau ide-ide baru akan mendorongnya untuk berwirausaha. Selain kelancaran, kelenturan (flexibility) atau 
kemampuan untuk menggunakan bermacammacam pendekatan dalam mengatasi persoalan juga mendorong mahasiswa untuk berwirausaha. Seorang yang kreatif disamping memiliki kelancaran dan kelenturan, juga harus memiliki kemampuan untuk mencetuskan gagasangagasan asli (originality) dan kemampuan untuk melakukan hal-hal secara detail terperinci (elaboration). Kreativitas yang tinggi ditandai dengan fluency, flexibility, originality, dan elaboration yang tinggi pula. Semakin tinggi kreativitas yang dibangun atas fluency, flexibility, originality, dan elaboration yang tinggi maka akan semakin memotivasi mahasiswa untuk berwirausaha.

\section{CONCLUSION}

Setelah dilakukan pengujian hipotesis maka hal yang dapat disimpulkan dari penelitian ini adalah bahwa kreativitas berpengaruh
Berdasarkan deskripsi variabel diketahui bahwa kretaivitas mahasiswa FE UNP masih cukup/sedang. Oleh sebab itu, mahasiswa harus meningkatkan kreativitasnya baik kelancaran dalam menghasilkan gagasan, kelenturan menggunakan berbagai pendekatan, keaslian mencetuskan gagasan asli, maupun kerincian dalam melakukan sesuatu untuk dapat lebih memotivasinya untuk berwirausaha. Hasil penelitian ini sejalan dengan penelitian yang dilakukan oleh Indah Fatmawati (2014) yang menemukan bahwa adanya miotivasi berwirausaha mahasiswa dipengaruhi oleh kreativitasnya.

signifikan dan positif terhadap motivasi berwirausaha mahasiswa FE UNP. 


\section{Bibliography}

[1]Andriani. 2013. Hubungan Antara Motivasi Orang Tua dalam Mendidik Anak Melalui PAUD dengan Partisipasinya di PAUD KAsih Ibu. Portal Garuda.Vol.1, No.1, April 2013. Pertalgaruda.org. diunduh pada 6 Maret 2015.

[2]Bangun, Wilson. 2012. Manajemen Sumber Daya Manusia. Jakarta : Erlangga.

[3]Fatmawati, Indah. 2014. Pengaruh Kreativitas Berwirausaha Dan Prestasi Belajar Kewirausahaan Terhadap Motivasi Berwirausaha Pada Mahasiswa Program Studi Pendidikan Akuntansi Fakultas Keguruan Dan Ilmu Pendidikan Universitas Muhammadiyah Surakarta Angkatan 2010/2011. FKIP UMS. Diunduh tanggal 24 November 2015.www.ums.ac.id.

[4]Greene, Chyntia L. 2008. Entrepreneurship. South-Western Cengage Learning : PrePress PMG
[5]McMullan, W. Edward dan Thomas $P$. Kenworthy. 2015. Creativity and Entrepreneurial Performance A General Scientific Theory. New York Dordrecht London : Springer International Publishing.

[6]Riduwan. 2010. Metode dan Teknik Menyusun Tesis. Bandung: Alfabeta

[7]Saiman, Leonardus. 2014. Kewirausahaan Teori Praktik dan Kasus-kasus. Jakarta: Salemba Empat

[8]Sardiman. 2012. Interaksi dan Motivasi Belajar Mengajar. Jakarta : PT. Raja Grafindo Persada.

[9]Suryana, Yuyus dan Kartib Bayu. 2013. Kewirausahaan Pendekatan Karakteristik Wirausahawan Sukses. Jakarta: Kencana Prenada Media Grup.

[10]Wijatno, Serian. 2009. Pengantar Entrepreneurship. Jakarta : Grasindo. 